\title{
AN EXPERIMENTAL STUDY ON EFFECTS OF WHEATGRASS (TRITICUM AESTIVUM) JUICE ON LOW DENSITY LIPOPROTIEN (LDL) LEVEL IN BLOOD OF EXPERIMENTALLY INDUCED HYPERCHOLESTEROLAEMIC MALE LONG EVANS RAT
}

\author{
ROKHSANA DIL AFROZ ${ }^{1}$, ABU SADAT MOHAMMAD NURUNNABI ${ }^{2}$, MD. ISMAIL KHAN ${ }^{3}$, TUHIN JAHAN ${ }^{4}$ \\ ${ }^{1}$ Assistant Professor, Department of Pharmacology \& Therapeutics, Shaheed Suhrawardy Medical College, Dhaka \\ ${ }^{2}$ Assistant Professor, Department of Anatomy, OSD, Directorate General of Health Services (DGHS), Dhaka \\ ${ }^{3}$ Professor and Head, Department of Pharmacology \& Therapeutics, Dhaka Medical College, Dhaka \\ ${ }^{4}$ Assistant Professor, Department of Pharmacology \& Therapeutics, Faridpur Medical College, Faridpur
}

\begin{abstract}
An experimental study was done to observe the hypocholesterolaemic effect of wheatgrass (Triticum aestivum) juice on experimentally induced hypercholesterolaemic rats, especially on serum low density lipoprotein ( $L D L$ ) level, which was carried out in the Department of Pharmacology \& Therapeutics, Dhaka Medical College, Dhaka, between July, 2009 and June, 2010. $A$ total number of 48 healthy adult male Long Evans rats (Norwegian strain) were used for the present study. 6 rats were taken in each group of total 8 groups treated differently with 1 control group. Rats of the first 5 groups were sacrificed at $29^{\text {th }}$ day and their serum total cholesterol levels were measured. The rest of the rats were sacrificed at $5^{7^{\text {th }}}$ day and their serum total cholesterol levels were measured. The mean serum $L D L$ of $10 \mathrm{ml} / \mathrm{kg}$ grass juice fed normal rats was decreased by $11.64 \%$ than that of the laboratory diet fed control group $(P<0.01)$. Serum $L D L$ of the group of rats treated with $10 \mathrm{ml} / \mathrm{kg}$ grass juice and $1 \%$ cholesterol diet were decreased by $36.59 \%$ than that of the hypercholesterolaemic control group $(P<0.001)$. Serum $L D L$ of the hypercholesterolaemic rats treated with $10 \mathrm{ml} / \mathrm{kg}$ grass juice for 28 days were decreased by $29.10 \%$, and in hypercholesterolaemic rats treated with $20 \mathrm{ml} / \mathrm{kg}$ grass juice for 28 days were decreased by $39.46 \%(P<0.001)$. Reduction of $L D L$ as evident on hypercholesterolaemic rats treated with $20 \mathrm{ml} / \mathrm{kg}$ grass juice, which was similar to hypercholesterolaemic rats treated with $0.14 \mathrm{mg} / \mathrm{kg}$ Atorvastatin for 28 days.
\end{abstract}

Keywords: Wheatgrass juice, Hypercholesterolaemia, Low density lipoprotein (LDL), Long Evans rat.

(Bangladesh J Physiol Pharmacol 2014;30(2):18-24)

\section{INTRODUCTION}

Plasma lipoproteins levels are major modifiable risk factors for cardiovascular disease. ${ }^{1}$ Increased levels of atherogenic lipoproteins especially low density lipoprotien (LDL) and also intermediate density lipoprotien (IDL) and possibly chylomicron remnants contribute to development of atherosclerosis. ${ }^{2}$ Treatment of hyperlipidaemia requires long term therapy, to which patient compliance is poor and they often discontinue therapy. ${ }^{3}$ The potential hepatotoxic effect of statins, nicotinic acid and fibrates show elevated serum aminotransferase activity in some patients treated with them. ${ }^{3-5}$ Raised creatinine kinase activity may lead to rhabdomyolysis rarely in some

Address for correspondence: Rokhsana Dil Afroz, Assistant Professor, Department of Pharmacology \& Therapeutics, Shaheed Suhrawardy Medical College, Dhaka patient treated with statins or fibrates. Fibrates also have modest risk of cholesterol gall stone. In a view to reduce the side effects of drugs, the use of herbal supplements has increased dramatically over the past 30 years. $^{6}$ Recently, the World Health Organization (WHO) estimated that $80 \%$ of people worldwide rely on herbal medicines for some part of their primary health care. $^{6}$

Fresh wheatgrass (Triticum aestivum Linn.) juice had shown lipid lowering effect on normal rats. ${ }^{7-9}$ It is used as a health improving adjuvant in several diseases including coronary artery disease in India as folk medicine. ${ }^{7}$ In the molecular level, chlorophyll is very similar to haemoglobin, which allows wheat grass to move quickly into the blood system through the liver to distribute its positive effects. ${ }^{10}$ However, to the best of our knowledge, experimental study on the lipid lowering effect of wheatgrass juice in hyperlipidaemic condition 
has not been done in our country previously. Hence, the current study was designed to observe the effect of wheatgrass ( $T$. aestivum) juice on increased low density lipoprotien (LDL) on experimentally induced hypercholesterolaemic rats.

\section{MATERIALS AND METHODS}

\section{Animals:}

The experiments was carried out upon Long Evans Rats (Rattus rattus) (Norwegian strain), which were obtained from Bangladesh Council of Scientific and Industrial Research (BCSIR), Dhaka. A total number of 48 adult male rats, aged 2-3 months and weighing about 140200 grams were included in this study. They were kept in the animal house of the Department of Pharmacology \& Therapeutics, Dhaka Medical College, Dhaka. The rats were kept in cages, acclimatized at $26-29^{\circ} \mathrm{C}$ and humidity, with a 12 hour light and dark cycle. They were allowed free access to standard laboratory diet and water ad libitum. Animals were randomly distributed into eight (8) groups having six (6) rats in each group.

\section{Drugs and chemicals:}

a) Fresh common wheat grass (Triticum aestivum) juice: The wheatgrass ( $T$. aestivum) used in this study was grown in the roof top garden. When grass was about 6 inches tall, it was cut $1 / 2$ inch above the surface of soil. Twenty grams of harvested fresh grass was grounded by grinder with $10 \mathrm{ml}$ of sterile water and the juice was squeezed out through four layers of wet muslin cloth. The filtrate was made to $20 \mathrm{ml}$ final volume with sterile water and administered as grass juice. Each day the fresh juice was prepared prior to administration.

b) Distilled water;

c) Standard laboratory diet; d) Fatty mixture: $1 \%$ cholesterol diet was prepared by dissolving $1 \mathrm{gm}$ of cholesterol in $100 \mathrm{ml}$ of olive oil, according to Jesmin ${ }^{11}$.

3. Kits for the estimation of serum cholesterol: Serum cholesterol was estimated by cholesterol liquicolor CHOD-PAP-Method (enzymatic colorimetric test with lipid clearing factor).

The experiment was carried out in the Department of Pharmacology \& Therapeutics, Dhaka Medical College, Dhaka, from July, 2009 to June, 2010. As described earlier, a total number of 48 healthy adult male Long Evans rats were used for the present study.

\section{Experiment design:}

Group A: This control group consists of six rats received standard laboratory diet and distilled water for 28 days.

Group B: This group of rats was fed standard laboratory diet, distilled water and $10 \mathrm{ml} / \mathrm{kg} 1 \%$ cholesterol diet through feeding tube for 28 days, according to Amin ${ }^{12}$.

Group C: This group was fed standard laboratory diet and $10 \mathrm{ml} / \mathrm{kg}$ grass juice.

Group D: This hypercholesterolaemic control group received standard laboratory diet and $10 \mathrm{ml} / \mathrm{kg} 1 \%$ cholesterol diet for 28 days.

Group E: This group had received 1\% Cholesterol diet along with $10 \mathrm{ml} / \mathrm{kg}$ fresh wheat grass juice to observe the preventive effect of grass juice.

Group F: This group received $10 \mathrm{ml} / \mathrm{kg} 1 \%$ cholesterol diet for 28 days followed by $10 \mathrm{ml} / \mathrm{kg}$ fresh grass juice for next 28 days.

Group G: This group was fed $10 \mathrm{ml} / \mathrm{kg} 1 \%$ cholesterol diet for 28 days followed by $20 \mathrm{ml} / \mathrm{kg}$ fresh grass juice for next 28 days.

Group $\mathrm{H}$ : This group received $10 \mathrm{ml} / \mathrm{kg} 1 \%$ cholesterol diet for 28 days followed by $0.14 \mathrm{mg} / \mathrm{kg}$ Atorvastatin (a lipid lowering agent) for next 28 days, according to Jesmin (2006). ${ }^{11}$ 


\section{Experiment I:}

This part of the experiment was carried out on first three groups of rats to observe the effect of $1 \%$ cholesterol diet and wheatgrass juice on serum LDL of normal rat.

\section{Normal Rats}

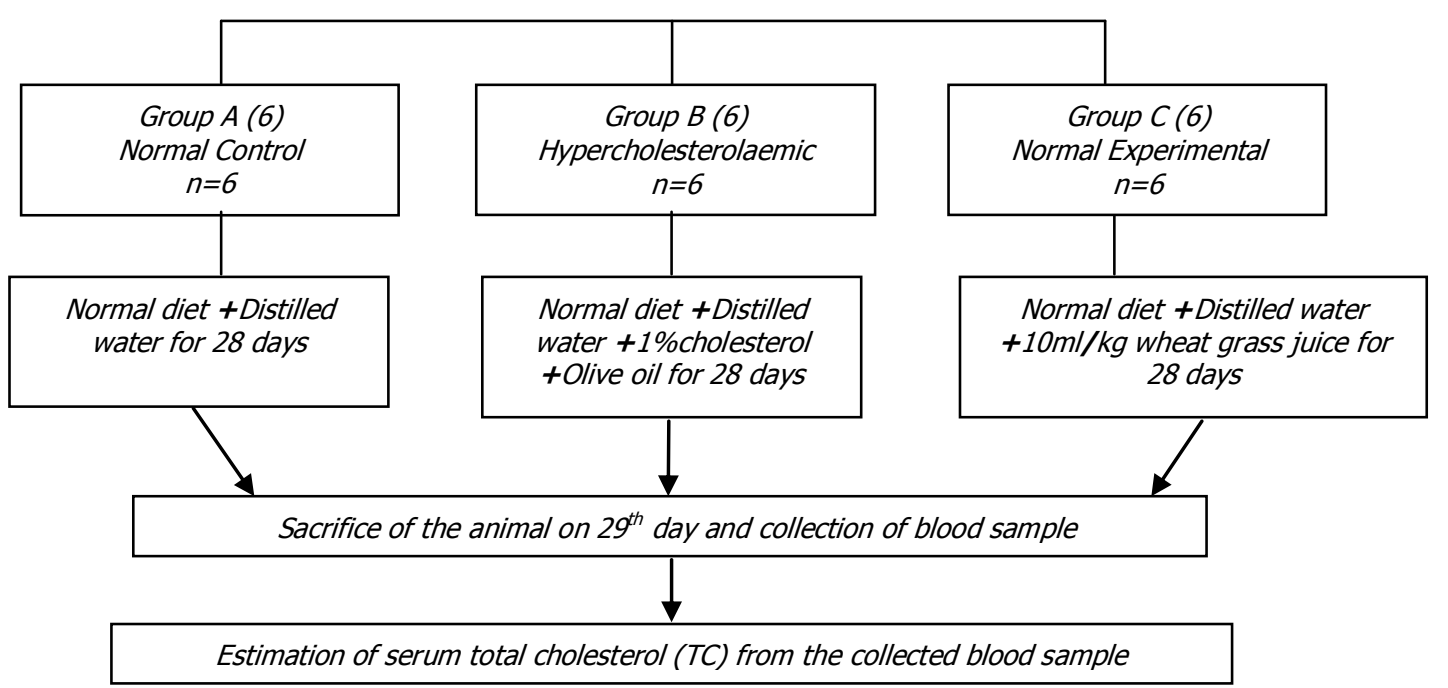

Fig. 1: Flow chart of experiment-I

\section{Experiment II:}

The rats of the experiment-II were fed $1 \%$ cholesterol diet $10 \mathrm{ml} / \mathrm{kg}$ or $1 \mathrm{ml} / 100 \mathrm{gm}$ of body weight for 28 days in order to elevate plasma cholesterol level, according to Amin $^{12}$.

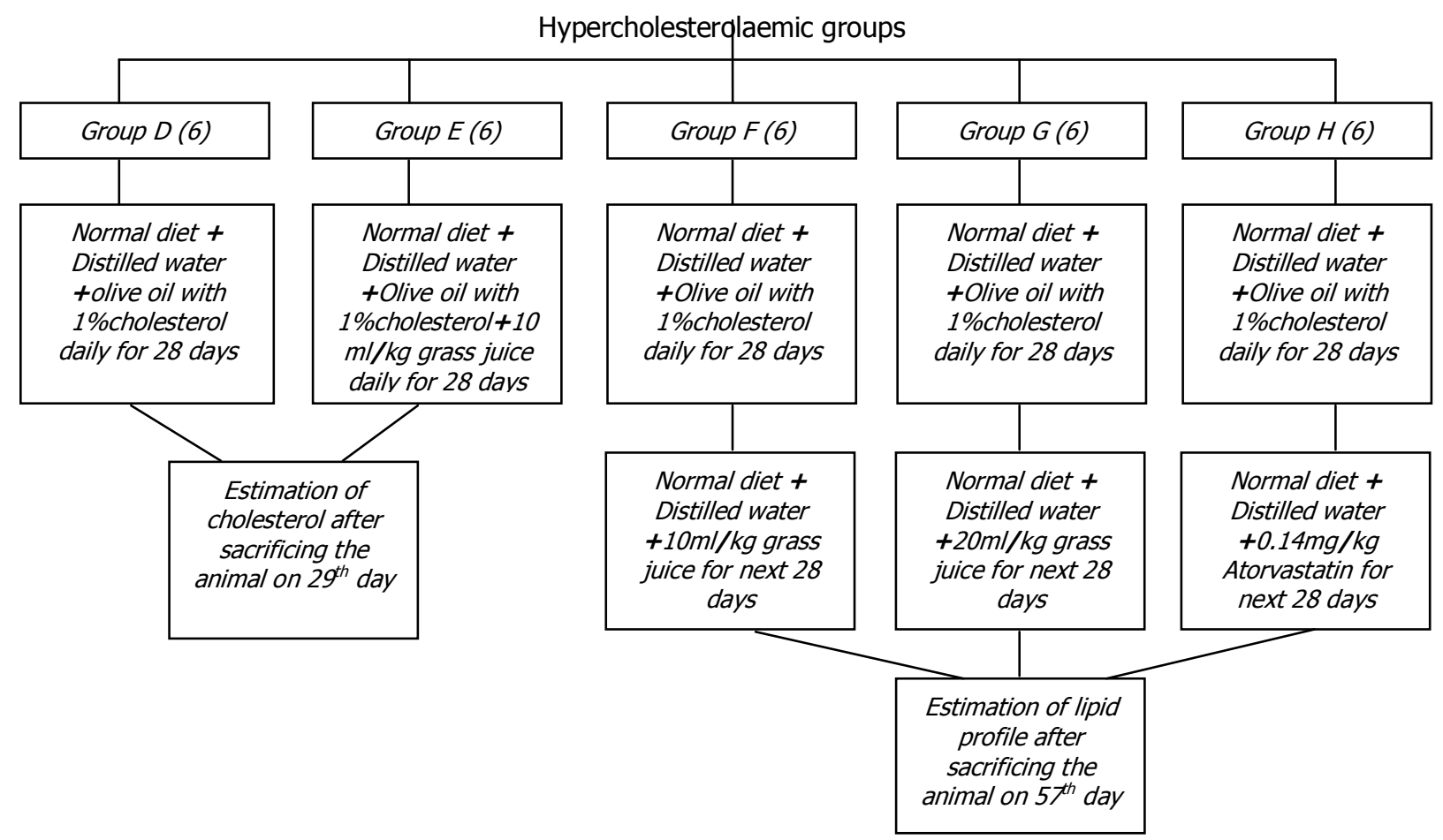

Fig. 2: Flow chart of experiment-II 


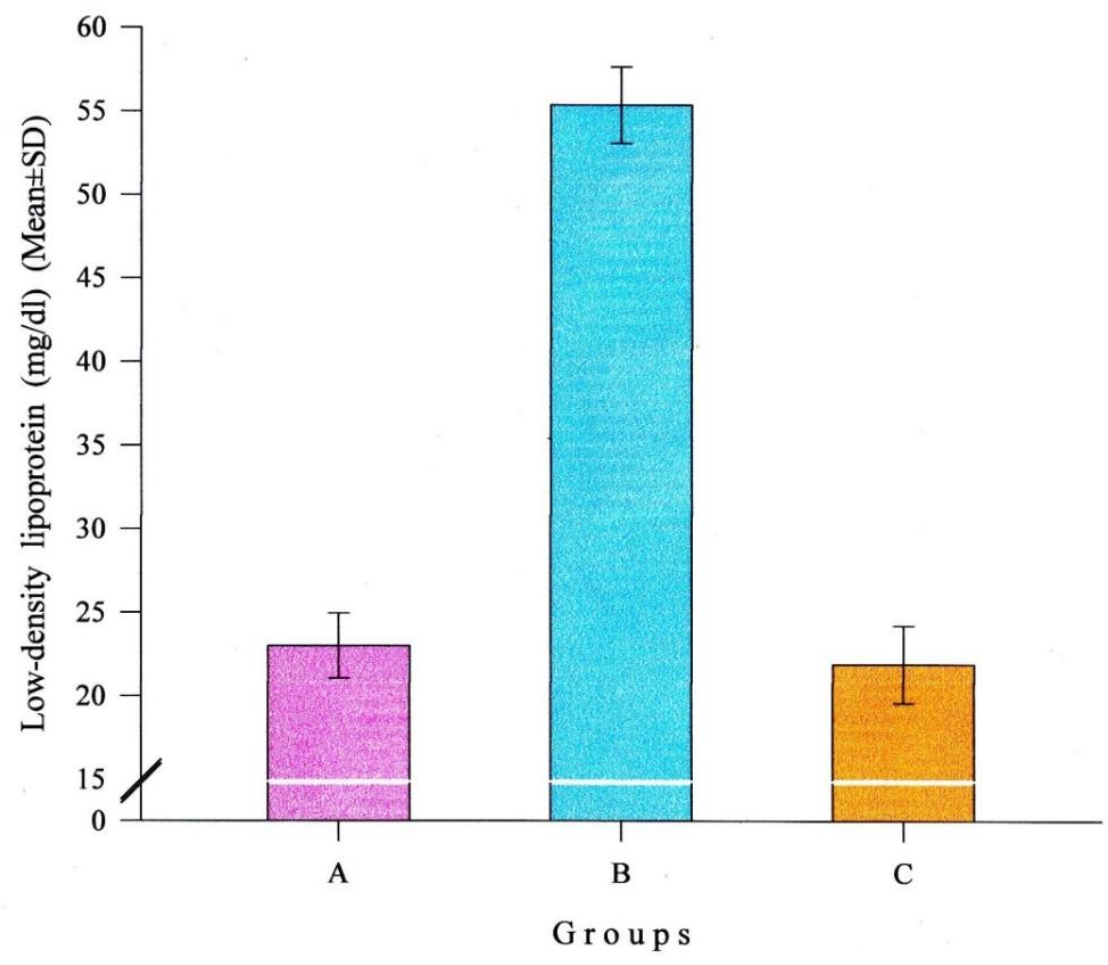

Fig. 3. Serum LDL levels in different group of rats in Experiment-I.

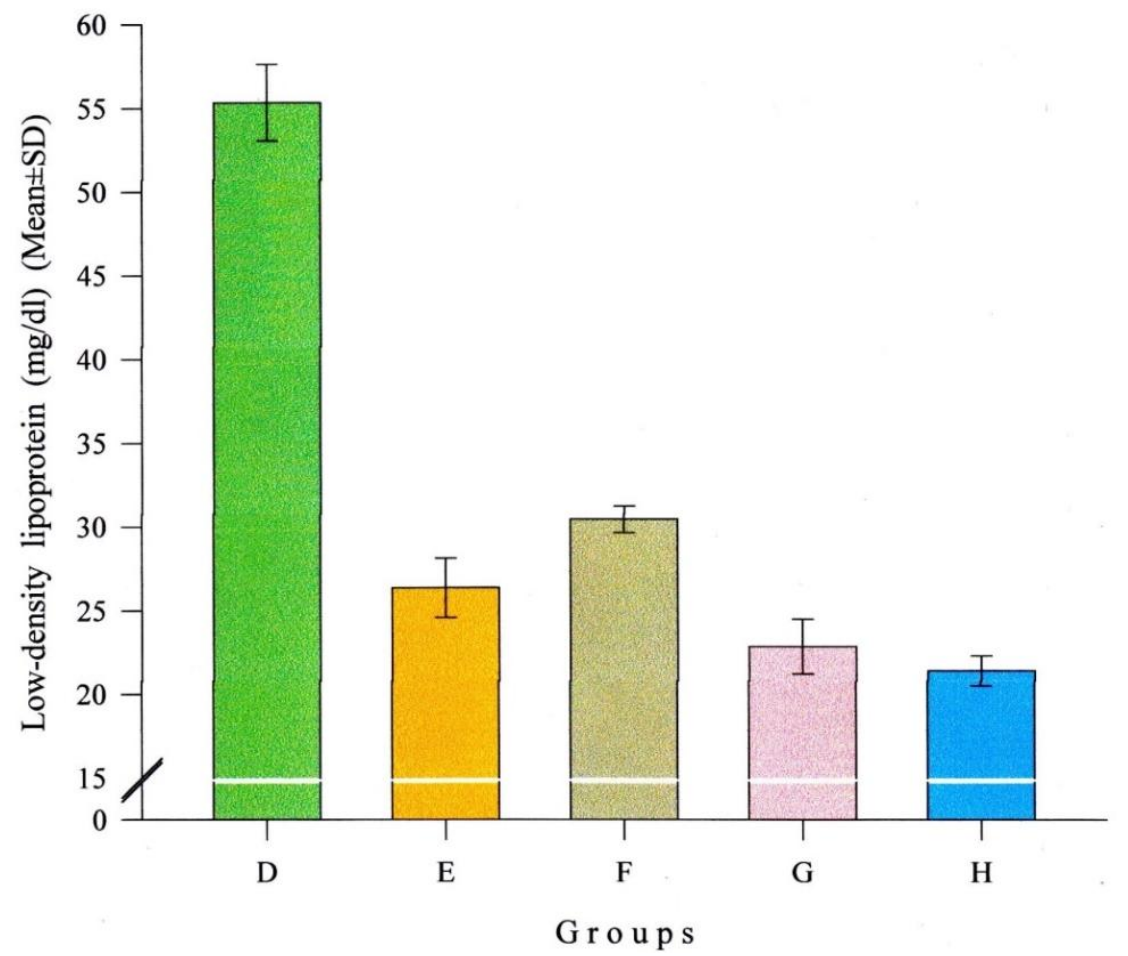

Fig. 4. Serum LDL levels in different group of rats in Experiment-II. 


\section{Table-I}

Serum LDL levels in different group of rats in Experiment-I

\begin{tabular}{llcll}
\hline Group & & $\begin{array}{c}\text { LDL Cholesterol (mg/dl) } \\
(\text { Mean } \pm \text { SD) }\end{array}$ & P value & Percent change \\
\hline A & $n$ & $23.01 \pm 1.95$ & & \\
B & 6 & $55.33 \pm 2.28$ & B vs A $0.0001^{* * *}$ & +142.07 \\
C & 6 & $18.17 \pm 2.62$ & C vs A $0.001^{* *}$ & -20.65 \\
\hline
\end{tabular}

Comparison of LDL levels between groups were done by unpaired Student's 't' test. ** $=$ Significant at $\mathrm{P}<0.01, * * *$ $=$ Significant at $\mathrm{P}<0.001$.

Group A : Control

Group B : Hypercholesterolaemic

Group C : : Laboratory diet plus grass juice

Table-II

Serum $L D L$ levels in different group of rats in Experiment-II

\begin{tabular}{llcll}
\hline Group & \multicolumn{2}{c}{$\begin{array}{c}\text { PDL-Cholesterol }(\mathrm{mg} / \mathrm{dl}) \\
(\text { Mean } \pm \text { SD })\end{array}$} & P value & \\
\hline D & $\mathrm{n}$ & $55.33 \pm 2.28$ & & \\
E & 6 & $26.36 \pm 1.77$ & E vs D $0.0001^{* * *}$ & -52.32 \\
F & 6 & $30.45 \pm 0.79$ & F vs D $0.0001^{* * *}$ & -44.87 \\
G & 6 & $22.85 \pm 1.64$ & G vs D $0.0001^{* * *}$ & -58.60 \\
H & 6 & $21.39 \pm 0.89$ & H vs D $0.0001^{* * *}$ & -61.27
\end{tabular}

between groups were done by unpaired Student's 't' test. $* * *=$ Significant at $\mathrm{P}<0.001$.

Group D : : Hypercholesterolaemic

Group E $\quad$ : $\quad 1 \%$ Cholesterol diet plus grass juice

Group F $\quad: \quad 1 \%$ Cholesterol followed by $10 \mathrm{ml} / \mathrm{kg}$ grass juice

Group G $\quad$ : $\quad 1 \%$ Cholesterol followed by $20 \mathrm{ml} / \mathrm{kg}$ grass juice

Group $\mathrm{H}$ : $\quad 1 \%$ Cholesterol followed by Atorvastatin

Table-III

Serum LDL levels in the groups of rats taken two different doses $(10 \mathrm{ml} / \mathrm{kg}$ and $20 \mathrm{ml} / \mathrm{kg}$ ) of grass juice in Experiment-II

\begin{tabular}{|c|c|c|c|c|}
\hline \multirow[b]{2}{*}{ Group } & \multirow{2}{*}{\multicolumn{2}{|c|}{$\begin{array}{l}\text { LDL-Cholesterol }(\mathrm{mg} / \mathrm{dl}) \\
(\text { Mean } \pm \text { SD })\end{array}$}} & \multicolumn{2}{|c|}{ Percent change } \\
\hline & & & $P$ value & (Mean) \\
\hline $\mathrm{F}$ & 6 & $30.45 \pm 0.79$ & & \\
\hline G & 6 & $22.85 \pm 1.64$ & $0.0001^{* * *}$ & -24.95 \\
\hline
\end{tabular}

Comparison of LDL levels between group $\mathrm{G}$ and group $\mathrm{F}$ was done by unpaired Student's 't' test. *** $=$ Significant at $\mathrm{P}<0.001$

Group F : $\quad 1 \%$ Cholesterol followed by $10 \mathrm{ml} / \mathrm{kg}$ grass juice

Group G $\quad$ : $\quad 1 \%$ Cholesterol followed by $20 \mathrm{ml} / \mathrm{kg}$ grass juice 
Table-IV

Serum LDL levels in the groups of rats taken higher dose $(20 \mathrm{ml} / \mathrm{kg})$ of grass juice to that of Atorvastatin in Experiment-II

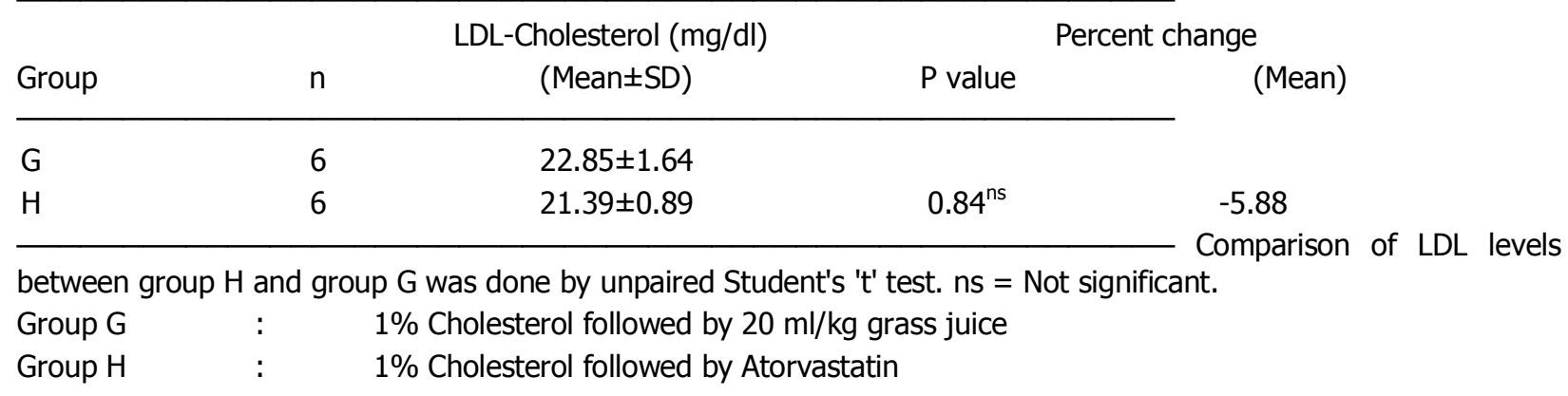

Each rat was fasted for 18 hours before sacrifice and collecting blood sample. They were given only water ad libitum during the fasting period. All animals were sacrificed under ketamine anaesthesia and blood samples were taken directly from the heart. Samples were collected in the test tubes. These were kept slanting position till blood had clotted. Serum was separated from the clot after centrifugation in the centrifuge machine. Serum was collected in small test tubes and kept at $0^{\circ} \mathrm{C}$. Then the serum was analyzed by the lipid profile kit.

Ethical Clearance: The present study was approved by the Ethical Review Committee of Dhaka Medical College, Dhaka.

\section{RESULTS}

Experiment-I:

Hyperlipidaemia was induced in rats by administration of $10 \mathrm{ml} / \mathrm{kg}$ body weight olive oil with $1 \%$ cholesterol through feeding tube for 28 days. Hyperlipidaemia was evident with a significant increase in serum TC, LDL and TG levels $(P<0.001)$ and decreased serum HDL level $(P<0.01)$.

Effect of $1 \%$ cholesterol diet on lipid profile of rats: The mean concentration of serum LDL was found to be increased by $58.27 \%$ in rats treated with $1 \%$ cholesterol diet compared to the rats fed normal diet, which was statistically highly significant $(P<0.0001)$ (Table-I, Fig. 3).

Effect of wheat grass juice on the lipid profile of normal rats: The mean serum LDL of $10 \mathrm{ml} / \mathrm{kg}$ grass juice fed normal rats was decreased by $11.64 \%$ than that of the laboratory diet fed control group. The result was statistically significant $(\mathrm{P}<0.0001)$ (Table-I, Fig. 3).

\section{Experiment-II:}

Effect of grass juice $(10 \mathrm{ml} / \mathrm{kg})$ when taken along with $1 \%$ cholesterol diet: The mean concentration of serum LDL of the group of rats treated with $10 \mathrm{ml} / \mathrm{kg}$ grass juice and $1 \%$ cholesterol diet were decreased by $36.59 \%$ than that of the hypercholesterolaemic control group, which was statistically significant $(P<0.001)$ (Table-II, Fig. 4).

Effect of grass juice $(10 \mathrm{ml} / \mathrm{kg})$ on hypercholesterolaemic rats: The mean serum concentration of LDL of the hypercholesterolaemic rats treated with $10 \mathrm{ml} / \mathrm{kg}$ grass juice for 28 days were decreased by $29.10 \%$, which was statistically highly significant $(P<0.001)$ (Table-II, Fig. 4).

Effect of grass juice $(20 \mathrm{ml} / \mathrm{kg})$ on hypercholesterolaemic rats: The mean serum concentration of LDL of the hypercholesterolaemic rats treated with $20 \mathrm{ml} / \mathrm{kg}$ grass juice for 28 days were decreased by $39.46 \%$, which was statistically highly significant $(P<0.001)$ (Table-II, Fig. 4).

Effect of Atorvastatin $(0.14 \mathrm{mg} / \mathrm{kg})$ on hypercholesterolaemic rats: The mean serum concentration of LDL of the hypercholesterolaemic rats treated with $0.14 \mathrm{mg} / \mathrm{kg}$ Atorvastatin for 28 days were found to be decreased by $38.86 \%$ than that of hypercholesterolemic control group, which was statistically highly significant $(P<0.001)$ (Table-II, Fig. 4).

Comparison of the effects of two different doses (10ml/kg and $20 \mathrm{ml} / \mathrm{kg}$ ) of grass juice: The serum LDL of the hypercholesterolaemic rat group treated with $20 \mathrm{ml} / \mathrm{kg}$ grass juice for 28 days was found to decrease more by $14.54 \%$ than that of the hypercholesterolemic rat group treated with $10 \mathrm{ml} / \mathrm{kg}$ grass juice for the same period, which was statistically highly significant $(\mathrm{P}<0.001)$ (Table-III, Fig. 4).

Comparison of the effects of the wheat grass juice $(20 \mathrm{ml} / \mathrm{kg})$ to that of with Atorvastatin $(0.14 \mathrm{mg} / \mathrm{kg}):$ In the present study, the reduction of serum LDL with the dose level of $20 \mathrm{ml} / \mathrm{kg}$ of grass juice $(39.46 \%)$ was found almost similar to that of Atorvastatin (38.86\%). The result statistically was not significant (Table-IV, Fig. 4). 


\section{DISCUSSION}

In the present study, hypolipidaemic effect of wheat grass juice was tested on adult Long Evans rats. Hyperlipidaemia was induced in rats by administration of $10 \mathrm{ml} / \mathrm{kg}$ body weight olive oil with $1 \%$ cholesterol through feeding tube for 28 days. Hyperlipidaemia was evident with a significant increase $(P<0.001)$ in serum TCL, LDL and TG levels. Besides, serum HDL level significantly decreased $\quad(P<0.01)$ Previous investigators. ${ }^{11-15}$ achieved similar effect on lipid levels by administering similar hyperlipidaemic diet. The results of their studies are more or less in agreement with that of the present study. The group of normal rats that took $10 \mathrm{ml} / \mathrm{kg}$ grass juice had shown significant reduction in serum total cholesterol. The result was in full agreement with that of Kothari et al. ${ }^{7}$ Administration of grass juice along with cholesterol diet also showed significant reduction of blood LDL level $(P<0.001)$ than the hypercholesterolaemic group. It indicates preventive role of grass juice against hypercholesterolaemia. Moreover, similar lipid lowering effects of wheat grass juice were evident in case of cholesterol ${ }^{16}$ and triglyceride $^{17}$ as per experiments done in the same set up. However, the lipid lowering effect of grass juice in the present study was found to be dose dependant. In higher dose level $(20 \mathrm{ml} / \mathrm{kg})$ of grass juice the lipid lowering effect was much more evident than that with lower dose $(10 \mathrm{ml} / \mathrm{kg})$. Kothari et al. ${ }^{7}$ also observed such changes in lipid parameters in dose related manner. In the present study, the reduction of serum LDL with the dose level of $20 \mathrm{ml} / \mathrm{kg}$ of grass juice $(39.46 \%)$ was found almost similar to that of Atorvastatin (38.86\%). However, the present study did not address the mechanisms by which grass juice produce lipid lowering effect. In fact, it is yet to be defined. However, several speculations have been made. The presence of alkaloids, tannins, saponins and sterols, as had been revealed by the preliminary phytochemical analysis may responsible for the lipid lowering effect of the wheat grass juice. $^{7}$ It was already recorded that, saponins have lipid lowering effects ${ }^{18}$ and tannins have been shown to affect lipid profile favourably through their effects on the lipoproteins, lipoprotein lipases and tissue lipids. ${ }^{19}$

\section{CONCLUSION}

The present study demonstrated LDL lowering effect of fresh wheatgrass ( $T$. aestivum) juice at hyperlipidaemic state. To the best of our knowledge, any study on the lipid lowering effect of wheatgrass juice in hyperlipidaemic condition has not been done in our country previously. Therefore, the result could not be correlated further with those of others. Further investigations are recommended to reconfirm and identify the hypolipidaemic mechanism of action. However, toxicological study should also be done before any clinical use.

\section{REFERENCES}

1. Ross R. Atherosclerosis - an inflammatory disease. N Engl J Med 1999; 340: 115-26.

2. Mayes PA, Botham KM. Cholesterol synthesis, transport and excretion. In: Murry RK, Granner DK, Mayes PA, Rodwell WV. eds. Harper's biochemistry. $28^{\text {th }}$ ed. New York: Lange; 2009: p.224-33.

3. Bloomfield P, Bradbury A, Grubb NR, Newby DE. Cardiovascular disease. In: Boon NA, Colledge NR, Walker BR. Davidson's principles and practice of medicine. $20^{\text {th }}$ ed. London: Churchill Livingstone; 2006: p.519-646.

4. Malloy MJ, Kane JP. Agents used in hyperlipidemia. In: Katzung BG. Basic and clinical pharmacology. $10^{\text {th }}$ ed. McGraw-Hill; 2007: p.560-72.

5. Gowland E. Lipids and lipoproteins. In: Mcmurry JR, Gowenlock AH, Mclauchlan DM. Practice of clinical biochemistry. $6^{\text {th }}$ ed. New Dehli: CBS Publishers; 1988: p. 452-76.

6. Wikipedia. Herbalism. Available from: http://en.wikipedia.org/wiki/Herbalism [Retrieved on April 9, 2012].

7. Kothari S, Jain AK, Mehta SC, Tonpay SD. Effect of fresh Triticum aestivum grass juice on lipid profile of normal rats. Indian J Pharmacol 2008; 40: 235-6.

8. Wikipedia. Wheatgrass. Available from: http://en.wikipedia.org/wiki/Wheatgrass [Retrieved on April 2, 2012].

9. Padalia S, Drabu S, Raheja I, Gupta A, Dhamija M. Multitude potential of wheatgrass juice (Green Blood): an overview. Chron Young Sci 2010; 1: 23-8.

10. Parkinson S. Natural Remedies - Wheatgrass. Natural Medicine. Available from: http://suite101.com/article/homeopathicremedies-wheatgrass-a210673 [Retrieved on April 7, 2012].

11. Jesmin S. Effects of Ctharanthus roseus Linn. on serum lipid profile in fat fed rats. [Thesis]. Dhaka: University of Dhaka; 2006.

12. Amin R. Study of the effect of Ganoderma Lucidum on serum lipid profile of hypercholesterolaemic rats. [Thesis]. Dhaka: University of Dhaka; 2009.

13. Akter R. Study of the effect of garlic on blood sugar and serum cholesterol level in normal rats and serum cholesterol level in fat fed rats. [Thesis]. Dhaka: University of Dhaka; 1982.

14. Lata S, Saxena KK, Bhasin V, Saxena RS, Kumar A, Srivastava VK. Beneficial effects of Allium sativum, Allium cepa and Commiphora mukul on experimental hyperlipidemia and atherosclerosis - a comparative evaluation. J Postgrad Med 1991; 37: 132-5.

15. Anita BS, Okokon JE. Effect of leaf juice of Catharanthus roseus Linn.) on cholesterol, triglyceride and lipoprotein levels in normal rats. Ind J Pharmacol 2005; 37: 401-2.

16. Afroz RD, Nurunnabi ASM, Khan MI. Effects of wheatgrass (Triticum aestivum) juice on serum cholesterol level in experimentally induced hypercholesterolaemic male Long Evans rat. Bangladesh J Physiol Pharmacol 2011; 27: 21-7.

17. Afroz RD, Nurunnabi ASM, Hossain MZ, Khan MI, Parvin S, Rahman $\mathrm{H}$. Study on effects of wheatgrass (Triticum aestivum) juice on serum triglyceride of experimentally induced hypercholesterolaemic male Long Evans rat. J Dhaka Med Coll 2012; 21: 197-203.

18. Lee KT, Soh IC, Kim DH, Chow JW, Kown SH, Park HJ. Hypoglycemic and hypolipidemic effects of tactorigenin and kaikasaponin III in streptozotocin-induced diabetic rats and their antioxidant activity. Arch Pharm Res 2000; 23: 461-6.

19. Tebib K, Besançon P, Rouanet JM. Dietary grape seed tannins affect lipoproteins, lipoprotein lipases and tissue lipids in rats fed hypercholesterolemic diets. J Nutr 1994; 124: 2451-7. 